\title{
SITUS-SITUS KEAGAMAAN DI KALIMANTAN
}

\author{
Bambang Sakti Wiku Atmojo* \\ Balai Arkeologi Banjarmasin, Jalan Gotong Royong II, RT. 03/06, Banjarbaru 70711, \\ Kalimantan Selatan; Telepon/facsimile +62 5114781716
}

Artikel masuk pada 4Januari 2012

Artikel selesai disunting pada 28 Maret 2012

\begin{abstract}
Abstrak.Situs-situs keagamaan di Kalimantan merupakan bukti bahwa wujud budaya bendawinya senafas dengan agama-agama yang berkembang di kawasan tersebut. Pada umumnya, warisan budayan religius tersebut berupa tempat peribadatan dan makam. Kajian ini dilakuan dengan pengamatan langsung di lapangan. Hasilnya menunjukkan bahwa empat agama besar telah berkembang di keempat provinsi di Kalimantan dan memperlihatkan elemen-elemen akulturasi dengan kebudayaan setempat. Selain itu, terdapat persamaan yang menarik pada situssitus keagamaan tersebut, yaitu keletakannya yang relatif dekat aliran sungai, yang merefleksikan kesinambungan budaya dari masa sebelumnya dalam pemilihan lokasi sakral.
\end{abstract}

Kata kunci: masjid, gereja, kelenteng, candi, prasasti, makam, tipe nisan, Islam, Kristen, Belanda, Cina, India, kaligrafi, arsitektur

Abstract. RELIGIOUS SITES IN KALIMANTAN. Religious sites in Kalimantan are evidences that the forms of cultural material represent the same spiritual 'breath' with the religions that developed in the region. In general, the religious cultural heritages consist of places of worship and cemeteries. This study was conducted by direct observation in the field. The results suggest the four major religions have grown in the four provinces in Kalimantan and show elements of acculturation with the local culture. In addition, there is an interesting similarity amongst these religious sites, which is their relatively close location to the river reflecting cultural continuity from the distant past in choosing a sacred space.

Keywords: mosque, church, temple, inscription, grave, types of tombstone, Islam, Christianity, Dutch, Chinese, India, calligraphy, architecture

\section{A. Pendahuluan}

Sejak resmi melaksanakan operasional pada tahun 1994, Balai Arkeologi Banjarmasin telah melakukan berbagai penelitian di sejumlah situs yang tersebar di empat provinsi wilayah kerja. Situs-situs yang telah diteliti meliputi situs dari berbagai kurun waktu, mulai masa prasejarah, perkembangan agama Hindu-Buddha, perkembangan agama Islam, kolonial Barat

\footnotetext{
* Penulis adalah Peneliti Madya pada Balai Arkeologi Banjarmasin, email: bambang.wiku@yahoo.com
} 
dan Timur, serta situs yang berkaitan dengan tradisi masyarakat, terutama dari masyarakat Dayak dan Banjar. Hasil penelitian Balai Arkeologi Banjarmasin menunjukkan bahwa di Kalimantan banyak terdapat berbagai jenis situs dan cagar budaya, di antaranya adalah situs yang bersifat keagamaan atau menunjukkan berasal dari ajaran agama tertentu. Paling tidak, terdapat situs-situs yang bersifat keagamaan yang berasal dari lima agama, yaitu Islam, Kristen, Katolik, Hindu, dan Buddha. Selain itu terdapat juga bangunan keagamaan yang merupakan tempat bersembahyang masyarakat Kong $\mathrm{Hu} \mathrm{Cu}$ dan Tao. Sebagian besar bangunan keagamaan yang ada telah masuk dalam kategori cagar budaya yang keberadaannya dilindungi oleh undang-undang.

Dalam Undang-Undang Nomor 11 tahun 2010 tentang Cagar Budaya, pada Bab I pasal 1 ayat 5 , yang disebut dengan situs cagar budaya adalah lokasi yang berada di darat dan/atau di air yang mengandung benda cagar budaya, bangunan cagar budaya, dan/ atau struktur cagar budaya sebagai hasil kegiatan manusia atau kejadian pada masa lalu. Pada pasal 1 ayat 1 disebutkan bahwa cagar budaya adalah warisan budaya bersifat kebendaan berupa benda cagar budaya, struktur cagar budaya, situs cagar budaya, dan kawasan cagar budaya di darat dan/atau di air yang perlu dilestarikan keberadaannya karena memiliki nilai penting bagi sejarah, ilmu pengetahuan, pendidikan, agama, dan/ atau kebudayaan melalui proses penetapan. Sedangkan dari segi usia pada pasal 5 disyaratkan berusia sekurang-kurangnya 50 tahun (Kementerian Kebudayaan dan Pariwisata 2011, 5, 6 dan 16).
Situs keagamaan dapat berupa bangunan yang digunakan untuk melaksanakan sembahyang harian, misalnya shalat bagi umat Islam, atau dapat juga berupa tempat atau bangunan yang menunjukkan identitas ajaran agama tertentu, misalnya makam. Banyaknya bangunan keagamaan menunjukkan bahwa kehidupan beragama cukup marak dan memiliki posisi yang strategis di masyarakat. Selain itu dapat juga dipakai sebagai penanda bahwa terdapat keragaman agama yang dipeluk masyarakat. Dapat dikatakan bahwa sebagian besar peninggalan keagamaan tersebut sekarang masih difungsikan oleh masyarakat. Hampir semua peninggalan keagamaan pada saat ini berada di kawasan pemukiman, meskipun sebagian di antaranya berada di tempat yang sekarang merupakan daerah jauh dari pemukiman penduduk.

Tulisan ini memaparkan beberapa situs keagamaan yang terdapat di wilayah kerja Balai Arkeologi Banjarmasin. Sebagian di antara situs tersebut telah ditetapkan pemerintah sebagai cagar budaya, namun sebagian yang lain belum memiliki surat penetapan sebagai cagar budaya. Meskipun demikian, dalam penulisan ini tidak ada perbedaan di antara keduanya, karena samasama merupakan peninggalan masa lalu yang harus dilestarikan keberadaannya sebagai warisan budaya masa lalu.

\section{B. Situs-situs Keagamaan \\ 1. Kalimantan Selatan}

Sebagian besar masyarakat Kalimantan Selatan memeluk agama Islam, sehingga sebagian besar peninggalan masa lalu juga berlatar belakang masyarakat 
pemeluk agama Islam. Ada dua jenis peninggalan yang dapat diidentifikasi, yaitu masjid dan makam atau kadang oleh masyarakat disebut kubah. Namun demikian terdapat juga situs keagamaan yang berlatar belakang non-Islam, di antaranya gereja, kelenteng, dan candi.

\section{a. Masjid}

Masjid dapat digolongkan dalam beberapa kategori, yaitu masjid kuna yang bersejarah, masjid kuna yang tidak bersejarah, dan masjid baru. Masjid baru tidak menjadi kajian arkeologi. Beberapa masjid kuna bersejarah di Kalimantan Selatan di antaranya adalah Masjid Sultan Suriansyah di Kuin (Banjarmasin) yang diyakini didirikan oleh Sultan Suriansyah pada abad ke-16 Masehi, Masjid Jami' Pasar Lama (di Banjarmasin), Masjid Banua Halat di Kab. Tapin yang dibangun sekitar tahun 1840 Masehi, Masjid Datuk Abulung di Kabupaten Banjar yang berasal dari masa sekitar 200 tahun yang lalu, Masjid Banua Lawas di Kabupaten Tabalong (secara turun temurun dikatakan berasal dari tahun 1625) yang juga dikeramatkan oleh masyarakat Maanyan, Masjid Tiang Tunggal di Batulicin (Kabupaten Tanah Bumbu) yang berasal dari tahun 1930, Masjid Martapura yang berasal dari tahun 1890-an (Kabupaten Banjar), Masjid Su'ada di Kabupaten Hulu Sungai Selatan yang dibangun tahun 1908, Masjid Jami' Sungai Banar yang didirikan pada tahun 1804, dan Masjid Agung Amuntai yang didirikan pada tahun 1950-an (keduanya di Kabupaten Hulu Sungai Utara). Sebenarnya masih ada sejumlah masjid kuna yang lain namun tidak terdata dengan jelas sehingga nilai kesejarahannya juga tidak diketahui.
Masjid-masjid kuna bersejarah tersebut sebagian besar sudah direnovasi berkali-kali sehingga bentuk maupun ukuran aslinya tidak terlihat lagi. Renovasi dilaksanakan baik karena bahan yang digunakan sudah lapuk dimakan usia maupun menyesuaikan dengan kebutuhan ruangan akibat meningkatnya jumlah pengguna masjid.

\section{b. Makam}

Makam yang dapat dianggap sebagai makam bersejarah hampir semua merupakan makam anggota keluarga kerajaan atau ulama penyebar agama Islam. Di Kuin (Banjarmasin), antara lain terdapat makam Sultan Suriansyah, Sultan Rakhmatullah, dan Sultan Hidayatullah. Mereka merupakan raja-raja yang memerintah ketika ibukota masih berada di Banjarmasin. Selain keempat raja tersebut, terdapat juga makam beberapa ulama dan pembesar kerajaan. Di dekat masjid Jami' Pasar Lama Banjarmasin juga terdapat makam Pangeran Antasari dan beberapa anggota keluarganya.

Di Kabupaten Banjar juga terdapat makam raja dan ulama, di antaranya makam Sultan Mustainbillah yang merupakan raja yang memimdahkan pusat pemerintahan Kerajaan Banjar dari Kuin di Banjarmasin ke Martapura. Makam raja-raja yang lain, yaitu Sultan Inayatullah, Tamjidillah, Sa'idullah, Tahlilullah, Badarul Alam (Sultan Kuning), Tahmidillah, Abdurrahman, Sultan Adam, dan Sultan Sulaiman Rahmatullah. Sedangkan makam ulama di antaranya adalah makam Syekh Arsyad al-Banjari dan Syekh Abdul Hamid Abulung. Keduanya merupakan ulama besar yang hidup pada masa Kerajaan Banjar. 
Di Kabupaten Tapin juga terdapat makam ulama terkenal yang sekarang dikenal dengan nama Datu Sanggul.

Selain itu, makam lainnya di antaranya adalah makam Syekh Muhammad Nafis di KabupatenTabalong, makam rajaraja Pagatan dan Koesan di Batulicin dan Pagatan, makam raja-raja dan ulama di Kotabaru, serta makam ulama penyebar agama Islam di Marabahan (Kabupaten Barito Kuala).

\section{c. Gereja}

Gereja di Kalimantan Selatan yang dapat dianggap sebagai situs bersejarah sangat jarang, namun ada satu yang dapat diidentifikasi, yaitu Gereja Katedral di Jalan Lambung Mangkurat, Banjarmasin yang berasal dari masa penjajahan Belanda. Gereja tersebut didirikan pada awal abad ke-20 dan sudah direnovasi sehingga bentuk dan ukuran aslinya juga sudah berubah.

\section{d. Candi}

Candi merupakan tempat peribadahan agama Hindu atau Buddha pada masa lalu. Sampai saat ini, candi yang ada di Kalimantan Selatan baru diketahui satu saja, yaitu Candi Agung yang terletak di Amuntai, Kabupaten Hulu Sungai Utara. Namun demikian, pada saat ini bangunan yang tersisa hanya bagian kaki paling bawah, sedangkan bagian badan dan kepala sudah tidak terlihat sama sekali. Sisa candi ini dahulunya diasumsikan sebagai tempat peribadahan agama Hindu. Sampai sekarang sisa bangunan candi ini masih dikeramatkan sebagian anggota masyarakat.

\section{e. Kelenteng}

Satu-satunya kelenteng yang dapat dikategorikan sebagai situs keagamaan di
Banjarmasin adalah kelenteng "Soetji Noerani" yang terletak di Jalan Pierre Tendean. Kelenteng ini merupakan sebuah Tridharma yang digunakan oleh para pemeluk agama Buddha, Kong $\mathrm{Hu}$ Tsu, dan Thao. Kelenteng tersebut diperkirakan didirikan pada tahun 1898. Meskipun Kelenteng ini juga sudah direnovasi sehingga terdapat beberapa perubahan dari bangunan aslinya, namun ditetapkan ebagai cagar budaya.

\section{Kalimantan Tengah}

Masyarakat Kalimantan Tengah pada masa lalu merupakan penganut kepercayaan asli yang sekarang dikenal dengan nama Kaharingan. Agama Islam dan Kristen baru masuk sekitar abad ke-17 Masehi. Agama Islam disebarkan oleh Kerajaan Banjar pada saat terjadi perluasan wilayah, sedangkan agama Kristen dibawa oleh misionaris dari Eropa. Namun demikian, bangunan-bangunan keagamaan yang berasal dari masa itu sangat sedikit.

Beberapa bangunan keagamaan yang dapat dikategorikan sebagai kuna dan bersejarah di antaranya adalah Masjid Kyai Gede di Kotawaringin Lama yang berasal dari abad ke -18 Masehi, makam-makam keluarga kerajaan dan ulama di Kotawaringin Lama (Kabupaten Kotawaringin Barat), masjid di Haringen (Kabupaten Barito Timur), Masjid Jami' di Muara Teweh (Kabupaten Barito Utara), Gereja di Mandomai (Kabupaten Kapuas), gereja di Tamiyang Layang yang didirkan sekitar tahun 1920 an (Kabupaten Barito Timur), dan makam-makam sekunder masyarakat pemeluk Kaharingan yang tersebar di berbagai tempat. Selain itu terdapat juga makam-makam Kristen keluarga 


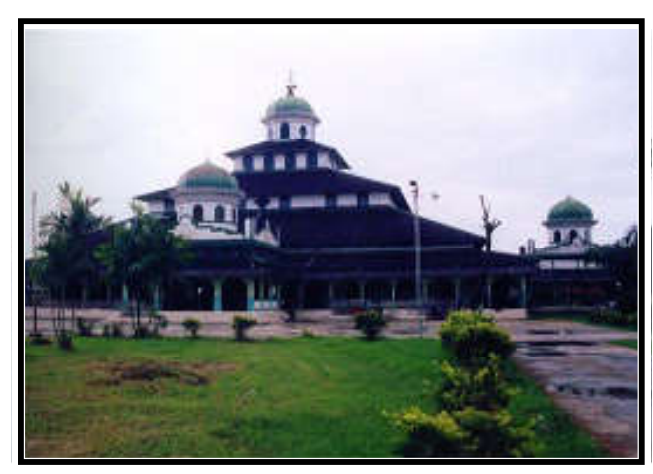

Foto 1. Masjid Jami' Pasar Lama, Banjarmasin, Kalimantan Selatan

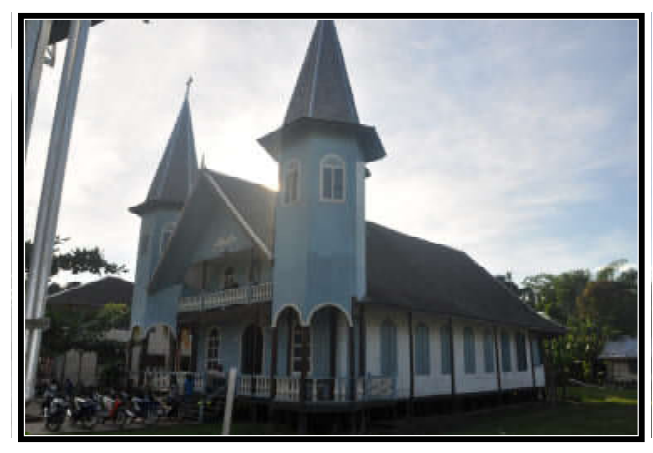

Foto 2. Gereja Immanuel di Mandomai, Kabupaten Kapuas, Kalimantan Tengah

Belanda di Muara Teweh (Kabupaten Barito Utara). Meskipun tidak ada angka yang tertera pada bangunannya, masjid dan gereja tersebut menurut cerita yang berkembang di masyarakat rata-rata berasal dari masa antara tahun 1920-1930.

\section{Kalimantan Timur}

Di wilayah Kalimantan Timur pada masa lalu terdapat sejumlah kerajaan yang sekarang wilayahnya menjadi kabupaten, antara lain Paser, Kutai, Berau, dan Bulungan. Kempat kerajaan tersebut berlatar belakang agama Islam, sehingga situs-situs keagamaan juga mencerminkan ajaran agama Islam, yaitu keberadaan masjid dan makam. Berdasarkan tradisi, agama Islam masuk ke Kalimantan Timur pada awal akhir abad ke 16 atau awal abad ke 17 Masehi, awalnya dibawa oleh ulama dari Makassar melalui pintu masuk Kerajaan Kutai. Agama Katolik baru masuk ke Kalimantan Timur pada akhir abad ke 19 atau awal abad 20, disebarkan oleh para misionaris Eropa. Selain itu terdapat juga penganut agama asli yang memiliki bangunan kubur sekunder sebagai bangunan keagamaannya.

\section{a. Masjid}

Situs-situs masjid kuna terutama berkaitan dengan eksistensi suatu kerajaan yang berlatar belakang agama Islam. Paling tidak terdapat enam masjid yang memiliki hubungan historis dengan kerajaan, yaitu di Bulungan (Masjid Sultan Kasimuddin), di Tanjung Redeb (Masjid Jami Gunung Tabur yang berusia sekitar 200 tahun dan Masjid Jami Sambaliung), di Tenggarong (Masjid Jami' Hasanuddin yang didirikan sekitar tahun 1897), di Samarinda (Masjid Shirotol Mustaqim), dan di Paser Balengkong (Masjid Jami' Nurul Ibadah). Masjid-masjid tersebut sampai saat ini masih menggunakan bahan bangunan kayu, meskipun semua sudah mengalami perombakan.

\section{b. Makam Islam}

Makam-makam Islam yang bersejarah hampir semuanya berada di lingkungan istana kerajaan atau kadangkadang di belakang masjid, kecuali di Paser Balengkong yang terpisah jauh dari masjid mapun istana. Sama halnya dengan masjid, 
makam-makam tersebut juga terkait dengan anggota keluarga kerajaan maupun tokoh penyebaran agama Islam. Di Bulungan, makam-makam anggota keluarga kerajaan terdapat di belakang Masjid Kasimuddin dan Gunung Seriang, sedangkan makam ulama terdapat di sebuah bukit di Tanjung Palas. Di Berau, makam-makam anggota keluarga raja dan ulama terdapat di Bukit Atap Seng, di belakang Istana Gunung Tabur, di Bangun Babanir, dan Batu Putih.

\section{c. Gereja}

Pada awalnya, agama Katolik disebarkan oleh para misionaris di pedalaman Sungai Mahakam, sekitar awal abad 20 Masehi. Diperkirakan, gereja paling tua ada di Laham, Long Iram, Kutai Barat. Namun demikian pada saat ini bangunannya sudah tidak ada sehingga sulit sekali membuktikan kebenarannya. Gereja-gereja yang dapat dikatakan kuna (seperti yang ada di Kutai Barat, Samarinda, dan Tarakan), semua berasal dari pertengahan abad 20 .

\section{d. Makam Belanda}

Makam Belanda kebanyakan merupakan makam tentara, meskipun ada juga makam warga sipil. Makam-makam ini antara lain terdapat di Kota Tarakan dan Teluk Bayur (Kabupaten Berau).

\section{e. Makam China}

Makam Cina yang memiliki angka tahun tertua terdapat di Tarakan, berasal dari tahun 1927, berupa makam seorang letnan. Hal ini terkait dengan migrasi masyarakat Cina ke pulau-pulau di selatan yang di Kalimantan Timur diperkirakan berlangsung mulai akhir abad ke-19, baik karena keinginan sendiri maupun karena didatangkan Belanda sebagai tenaga kerja.
Selain apa yang sudah diuraikan di atas terdapat juga bangunan keagamaan yang merupakan milik masyarakat Dayak, berupa makam sekunder, di antaranya terdapat di Kutai Barat, Bulungan, dan Malinau

\section{Kalimantan Barat}

Hasil penelitian arkeologi di Kalimantan Barat menunjukkan bahwa di wilayah tersebut terdapat berbagai jenis situs keagamaan, baik dari masa Hindu-Buddha, Islam, Kong $\mathrm{Hu} \mathrm{Cu}$ maupun Tao. Situs keagamaan ini tersebar di sejumlah kabupaten, baik berada di daerah aliran sungai yang merupakan jalan raya tradisional maupun yang jauh dari daerah aliran sungai, bahkan ada juga yang berada di daerah kepulauan.

\section{a. Masjid}

Pada umumnya masjid-masjid yang merupakan bangunan kuna bersejarah didirikan oleh kerajaan yang menguasai suatu wilayah tertentu. Tercatat, paling tidak terdapat 8 situs masjid kuna yaitu Masjid Jami' Sultan SyarifAbdurrahman di Pontianak yang berasal dari akhir abad ke-19, Masjid Jami' Muhammad Tsafiuddin Kesultanan Sambas yang dibangun tahun 1885, Masjid Jamiatul Khair di Mempawah yang dibangun tahun 1906, Masjid Jami' Ngabang di Landak, Masjid Jami' Sultan Nata di Sintang yang berasal dari tahun.1690 an, Masjid Jami' Sekadau, Masjid Jami' Sultan Ayub di Sanggau, Masjid Jami' Darussalam di Tayan, dan Masjid Matan di Kabupaten Ketapang. Masjid-masjid tersebut rata-rata berada di lingkungan istana sebagai pusat pemerintahan, dan terletak tidak jauh dari aliran sungai besar yang merupakan jalur lalu lintas yang cukup ramai. 


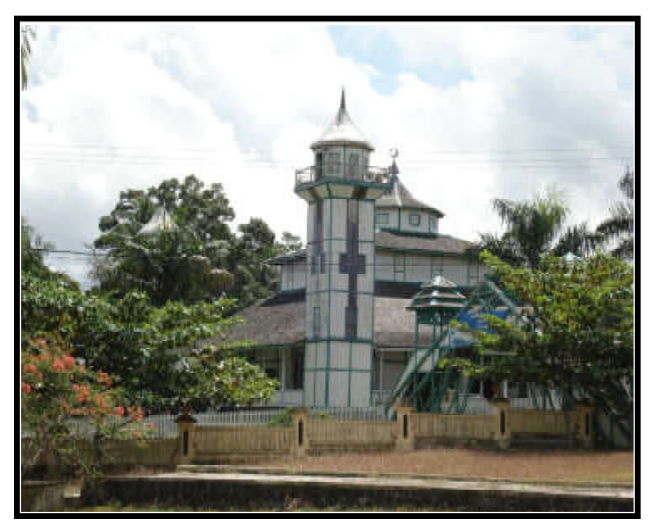

Foto 3. Masjid Jami Sultan Nata di Sintang, Kalimantan Barat

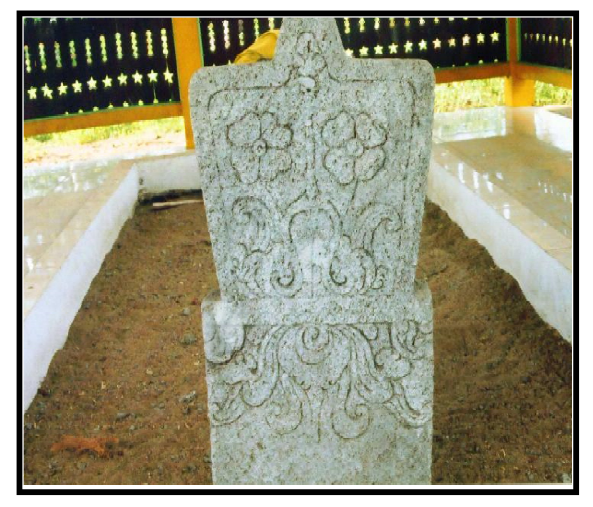

Foto 4. Salah satu nisan makam kuno di Ketapang yang berasal dari abad ke-15 Masehi

\section{b. Makam}

Makam-makam Islam hampir semuanya merupakan makam raja-raja atau ulama kerajaan, dan letaknya tidak jauh dari kompleks istana dan masjid kerajaan. Namun demikian, ada juga yang letaknya tidak berdekatan dengan istana, misalnya makam Daeng Manambon di Sebukit Rama (Kabupaten Pontianak), makam anggota keluarga kerajaan di Batulayang (Kota Pontianak) serta makam raja-raja di Mengkiyang dan Tayan (Kabupaten
Sanggau). Makam raja-raja yang berada tidak jauh dari kompleks istana antara lain terdapat di Sambas, Kota Sanggau, dan Sintang. Makam-makam paling tua terdapat di Kabupaten Ketapang, berasal dari abad ke15 - 16 Masehi, dikenal dengan nama kompleks makam tujuh dan makam sembilan.

\section{c. Situs Hindu-Buddha}

Situs keagamaan dengan latar belakang agama Hindu berupa candi sejauh ini baru ditemukan satu, yaitu di Negeri Baru, Kabupaten Ketapang. Candi ini merupakan candi kedua yang ditemukan di Kalimantan selain candi Agung di Kalimantan Selatan, tetapi belum dapat diketahui secara pasti periodisasinya. Situs keagamaan agama Buddha terdapat di Kabupaten Sekadau berupa prasasti yang berisi mantera-mantera agama Buddha serta prasasti di Pulau Maya, Kabupaten Kayong Utara yang bergambar caitra. Keduanya diperkirakan berasal dari abad ke-6 Masehi.

\section{d. Kelenteng/Toa Pe Kong}

Hampir semua kelenteng/toa pe kong bersejarah terdapat di Singkawang, yang memang mayoritas penduduknya keturunan Tiong Hoa. Di antara kelenteng-kelenteng tua tersebut adalah Kelenteng Sun Go Kong di Desa Kulor, Kecamatan Singkawang Tengah, Kelenteng Tri Dharma Bumi Raya di Pusat Kota, Kelenteng Koa Sin Ti Kiun di Desa Kaliasin, dan Kelenteng Ngkuk Shin Ti yang terletak di tengah-tengah persawahan, dengan jalan kecil yang menghubungkan dengan jalan besar di Desa Pasiran, Kecamatan Singkawang Barat. Cerita yang berkembang menyatakan bahwa rata-rata bangunan tersebut berasal dari abad ke-19 dan awal abad ke-20 Masehi. 


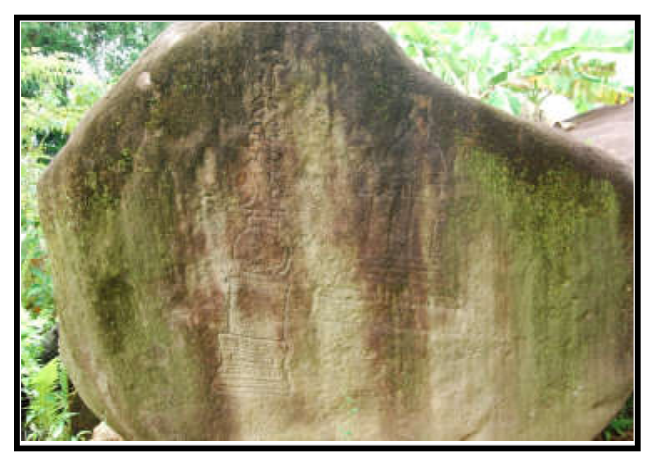

Foto 5. Relief stupa di Pulau Maya, Kabupaten Kayong Utara, Kalimantan Barat

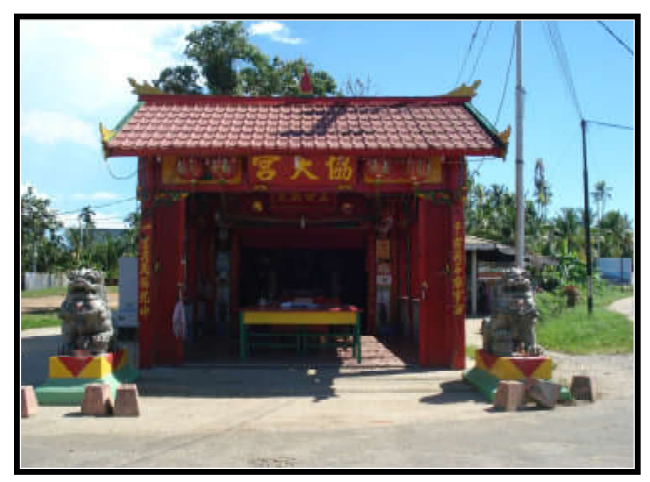

Foto 6. Kelenteng di Desa Kaliasin, Singkawang, Kalimantan Barat

\section{Situs-situs Keagamaan dalam Lintas Budaya: Suatu Pembahasan}

Berbagai jenis bangunan yang telah diuraikan di atas dimiliki oleh beberapa penganut agama, yaitu Islam berupa masjid dan makam, Kristen (tanpa membedakan Protestan dan Katolik) berupa gereja, Hindu berupa candi, sedangkan Buddha, Kong $\mathrm{Hu}$ $\mathrm{Cu}$ dan Tao berupa kelenteng. Selain itu, terdapat juga bangunan keagamaan yang dapat dianggap sebagai asli Kalimantan, yang dimiliki oleh masyarakat Dayak. Munculnya bangunan keagamaan menunjukkan bahwa kebutuhan untuk berhubungan dengan Tuhan atau kehidupan spiritual merupakan sesuatu yang mutlak dalam kehidupan manusia. Munculnya berbagai bangunan keagamaan tersebut memunculkan suatu peradaban yang khas, karena memiliki fungsi dan bentuk yang cukup berbeda dengan berbagai bangunan yang digunakan di luar fungsi keagamaan. Meskipun sebagian besar bangunan tersebut memiliki latar belakang keagamaan yang berasal dari luar Indonesia, namun telah membentuk sebuah peradaban yang mewarnai perjalanan sejarah Indonesia, khususnya di Kalimantan.

Kalimantan sebagai bagian dari Indonesia, merupakan sebuah kawasan yang dilintasi rute-rute perdagangan besar yang menghubungkan India dengan Cina, serta kawasan Timur Tengah. Salah satu efeknya adalah Kalimantan mengalami persentuhan dengan berbagai ideologi dan agama yang pernah berkembang pada jalur perdagangan tersebut. Agama-agama besar dari India, yaitu Hindu dan Buddha, telah masuk sejak abad ke 4 Masehi dan berkembang selama beberapa abad. Perkembangan ini ditandai dengan adanya peninggalan berupa prasasti, lingga, dan candi. Prasasti ditemukan di Kalimantan Barat dan Kalimantan Timur serta sebuah pecahan di Kalimantan Selatan. Lingga, banyak ditemukan di Kalimantan Barat, terutama di daerah aliran Sungai Kapuas dan anak-anak sungainya, sedangkan candi ditemukan terdapat di Kalimantan Barat dan Kalimantan Selatan. Pertanggalan absolut dari peninggalan-peninggalan tersebut tidak diketahui, namun secara relatif dapat dikatakan berasal dari masa antara abad ke-4 s.d. abad ke-14 Masehi. Oleh karena sebagian besar merupakan bangunan 
yang tidak memiliki ruang, maka sumbangan terhadap sejarah perkembangan arsitektur tidak banyak.

Meskipun memiliki rentang waktu perkembangan yang cukup lama, namun kedua agama tersebut tidak dapat berkembang secara meluas menjadi sebuah ideologi yang besar, karena kemudian terdesak setelah munculnya agama Islam dan Kristen. Hal ini dibuktikan dengan jumlah bangunan keagamaan Islam dan Kristen yang jauh lebih banyak dibandingkan dengan Hindu, Buddha, maupun agama-agama dari Cina. Pada saat ini agama Hindu banyak dianut oleh masyarakat Bali yang menjadi transmigran dan sebagian masyarakat Dayak, sedangkan agama Buddha dan agama-agama dari Cina banyak dipeluk oleh masyarakat keturunan Cina.

Prasasti di Kalimantan dapat dikatakan berlatar belakang agama Buddha dan Islam. Prasasti yang berasal dari agama Buddha terdapat di Kabupaten Sekadau, yaitu prasasti Batu Pahit, dipahatkan pada sebuah batu besar, berisi mantera-mantera dalam agama Buddha sehingga dapat dikategorikan sebagai bangunan keagamaan. Di dalam prasasti tersebut antara lain terdapat pahatan 7 stupa dan chattra susun 13 di atasnya, dan terdapat juga pahatan posa masa cake 578 atau bulan Posa tahun Caka 578 (Atmodjo dalam Bambang Sulistyanto dkk. 1994, 2). Selain itu terdapat juga sebuah prasasti yang berupa gambar caitra di Pulau Maya, Kabupaten Kayong Utara. Kedua prasasti tersebut merupakan suatu indikasi bahwa sekitar 1300 tahun yang lalu telah terdapat sebuah peradaban masyarakat Buddha di Kalimantan Barat. Apabila dibandingkan dengan mukhalingga di Sepauk yang diperkirakan berasal dari abad ke -7 Masehi, maka dapat dikatakan bahwa perkembangan agama Hindu dan Buddha berjalan secara bersama-bersama pada waktu yang hampir bersamaan.

Adanya candi sebagai suatu bangunan pemujaan menunjukkan bahwa pada masa lalu terdapat penganut agama Hindu ataupun Buddha yang cukup banyak dan telah bermukim secara tetap. Meskipun jumlah pasti penganut agama-agama tersebut belum dapat diketahui, namun karena memerlukan tempat beribadah yang layak maka dibangunlah candi. Sayang sekali bahwa siapa pembangun candi baik di Amuntai (Kalimantan Selatan) maupun Negeri Baru (Kalimantan Barat) belum diketahui sampai dengan saat ini. Adanya bangunan candi itu juga menunjukkan bahwa telah terdapat lapisan-lapisan sosial dalam masyarakat, karena tentunya ada pendeta, arsitek, pekerja, serta masyarakat pengguna. Apabila dilihat dari jumlahnya yang lebih dari satu, maka candi di Negeri Baru kemungkinan bukan hanya merupakan candi tingkat desa.

Prasasti yang berlatar belakang agama Islam terdapat pada makam-makam anggota keluarga kerajaan, seperti yang terdapat di Kalimantan Timur dan Kalimantan Selatan. Dikatakan sebagai bangunan keagamaan karena dalam agama Islam, orang yang meninggal wajib dimakamkan. Di dalam prasasti tersebut sebagian di antaranya menunjukkan bahwa adanya ajaran yang berasal dari Al Qur"an sehingga dapat dikatakan sebagai bentuk lain dari dakwah. Pada umumnya prasasti pada makam tersebut berasal dari abad ke-18 dan abad ke-19 Masehi. Pada saat itu, di Kalimantan Timur berkembang lima kerajaan yaitu 
Bulungan, Sambaliung, Gunung Tabur, Kutai Kertanegara, dan Paser, sedangkan di Kalimantan Selatan berkembang kerajaan Banjar, Pagatan dan Kusan, Batulicin, serta Sigam.

Di Kabupaten Ketapang Kalimantan Barat terdapat dua kompleks makam yaitu keramat tujuh dan keramat sembilan. Nisannisan pada kedua kompleks makam tersebut sangat mirip dengan nisan pada kompleks makam Troloyo di bekas pusat kota Majapahit, yaitu Trowulan. Pada kedua kompleks makam tersebut terdapat angkaangka tahun yang ditulis menggunakan huruf Jawa Kuna, dan menunjukkan berasal dari tahun 1400-an Masehi. Angka-angka tersebut sejauh ini merupakan angka yang tertua dalam proses perkembangan agama Islam di Kalimantan.

Bentuk-bentuk nisan beserta ragam hiasnya di Kalimantan menunjukkan adanya budaya dari berbagai daerah yang masuk kawasan ini. Dari segi bentuk, paling tidak terdapat tiga langgam yang ada, yaitu langgam Aceh, Bugis-Makassar, dan Demak Troloyo. Ragam hias yang ada juga menunjukkan adanya keragaman budaya, yaitu sulur-suluran bergaya Jawa, kaligrafi menggunakan huruf dan gaya Arab, dan kaligrafi huruf Bugis. Bisa saja hal tersebut menunjukkan asal-usul para penyebar agama Islam di Kalimantan.

Makam, pada gilirannya yang kemudian, berfungsi sebagai tempat berziarah, dan tradisi ziarah ini berkembang secara meluas. Ziarah bukan hanya terbatas di kalangan pemeluk agam Islam tetapi meluas kepada pemeluk agam lain. Di kalangan umat Islam ada beberapa alasan mengapa orang melakukan ziarah, di antaranya adalah mengingat kepada kematian, menjaga hubungan batin antara yang masih hidup dengan yang sudah meninggal, dan mengirim doa untuk kebaikan orang yang sudah meninggal. Meskipun sebenarnya tradisi ziarah berasal dari masa pra Islam, tetapi tradisi ini dalam agama Islam mendapatkan porsi yang cukup penting, apalagi pada makam-makam yang dianggap keramat, misalnya makam para wali atau ulama penyebar agama Islam. Di Kalimantan Selatan bahkan pada masjid-masjid kuna juga dijadikan sebagai tempat ziarah, karena dianggap sebagai tempat keramat.

Masjid merupakan tempat untuk melaksanakan ibadah shalat lima waktu dan shalat Jumat. Menurut fungsi dan bentuknya ada beberapa istilah untuk masjid, yaitu masjid jami', masjid makam atau masyad, masjid agung atau masjid negara, masjid madrasah, masjid pesantren, dan masjid wanita. Masjid jami yaitu masjid yang biasa digunakan untuk shalat jum"at, masjid makam yaitu masjid yang biasanya didirikan di kompleks pemakaman, masjid agung atau masjid negara biasanya merupakan masjid besar yang terletak di pusat pemerintahan dan menjadi simbol kekuasaan, masjid masdrasah yaitu masjid yang sekaligus digunakan untuk sekolah atau madrasah, masjid pesantren adalah masjid yang berada di lingkungan pesantren, sedangkan masjid wanita merupakan masjid yang khusus diperuntukkan bagi kaum perempuan untuk shalat dan pengajian (Anom dkk 1999, 7-8).

Pada umumnya, atap masjid-masjid kuna berbentuk tumpang, antara satu sampai lima. Ada sebagian masjid kuna yang tetap mempertahanankan bentuk atap tersebut meskipun sudah beberapa kali dipugar. Beberapa masjid kuna yang masih tetap 
mempertahankan bentuk atap tersebut, antara lain Masjid Sultan Abdurrahan di Pontianak, Masjid Kyai Gede di Kotawaringin Lama (Kalimantan Tengah), Masjid Sultan Suriansyah di Banjarmasin, Masjid Hasanudin di Tenggarong, dan Masjid Wasah Hilir di Kandangan, Kalimantan Selatan. Bentuk atap yang tumpang tampaknya merata ada di berbagai tempat di seluruh Indonesia. Di Kalimantan, hampir semua masjid kuna berada di tengah kota, dekat dengan istana sebagai pusat pemerintahan pada zaman kerajaan.

Hampir semua masjid kuna berada tidak jauh dari aliran sungai, misalnya Masjid Sultan Abdurrahman yang berada di dekat pertemuan Sungai Kapuas dan Landak, Masjid Sultan Suriansyah yang berada di tepian Sungai Kuin, dan Masjid Mempawah yang berada di tepian Sungai Mempawah. Pada umumnya, masjid-masjid kuna di Kalimantan berbentuk panggung, karena kondisi daratannya sebagian merupakan rawa dan sebagian yang lain meskipun bukan merupakan rawa namun kondisinya tidak rata. Sekitar masjid merupakan sebuah kawasan pemukiman yang ramai didiami penduduk. Melihat pada kondisi tersebut ada dua kemungkinan yang terjadi. Kemungkinan pertama, masjid didirikan di perkampungan yang telah didiami penduduk, atau kemungkinan kedua penduduk datang ke kawasan tersebut setelah adanya bangunan masjid untuk melaksanakan kegiatan ibadah. Pada Masjid Pusaka Banua Lawas di Kabupaten Tabalong, Kalimantan Selatan, menurut cerita turun temurun didirikan di atas reruntuhan bangunan tempat beribadah agama pra Islam. Di tebing sungai yang mengalir di samping masjid tersebut, pada saat musim kemarau seringkali terlihat bata merah bersusun.

Dalam struktur tata kota kerajaankerajaan masa pengaruh Islam, masjid bersama dengan istana dan pasar merupakan satu kesatuan pembentuk kota kerajaan. Istana merupakan pusat pemerintahan, tempat semua keputusan politik kerajaan dirumuskan dan diputuskan. Istana biasanya bukan merupakan bangunan tunggal namun merupakan suatu kompleks, di mana anggota keluarga kerajaan bertempat tinggal. Berdasarkan sejarahnya, istana dan masjid biasanya saling berhubungan dan merupakan satu kesatuan. Pada awal peradaban manusia, kota bahkan tumbuh dari pusatpusat pemujaan yang isinya bangunan kuil, candi, dan istana, yang dibangun oleh para penguasa masyarakat setelah hasil pertanian menunjukkan hasil yang berlebih (Daljoeni 1998, 39).

Pada sejumlah kasus, makam para ulama berada di dekat masjid yang mereka dirikan, yang kemudian diikuti oleh para pengikut mereka yang dimakamkan di dekat masjid tersebut. Namun demikian, ada juga masjid yang didirikan di dekat makam tokoh yang dikeramatkan. Menyangkut pada kasus tersebut, masjid dan makam memang merupakan tempat-tempat keramat yang seringkali merupakan satu kesatuan inti dari sebuah kompleks yang pada umumnya terletak di tengah sebuah kota atau di pinggirannya (Guillot dan Loir dalam Loir dan Guillot 2007, 338).

Banyaknya peninggalan yang berlatar belakang agama Islam di Kalimantan menunjukkan bahwa daerah-daerah tersebut hanya mendapatkan sedikit pengaruh agama Hindu-Buddha sebelum Islam datang. Salah 
satu contohnya adalah di Banjar, di mana agama Islam berkembang pesat dan didukung oleh penguasa kerajaan. Hal ini antara lain terlihat dari banyaknya peninggalan yang berupa masjid yang sampai saat ini masih eksis. Meskipun sebelumnya telah berkembang agama non Islam, namun setelah berkembangnya agama Islam kehidupan masyarakat banyak dipengaruhi oleh nilai-nilai Islam. Kedudukan sultan di Banjar bukan hanya pemegang kekuasaan dalam kerajaan, tetapi lebih jauh diakui sebagai ulil amri kaum muslimin di seluruh wilayah Kerajaan (Thohir 2004, 294).

Berbeda dengan agama Islam yang dibawa oleh orang-orang Asia, gereja-gereja di Kalimantan pada umumnya didirkan oleh para misionaris dari Eropa, di antaranya Belanda dan Jerman. Mereka masuk ke Kalimantan mengikuti perluasan wilayah yang dilaksanakan oleh Pemerintah Hindia belanda, meskipun tidak ada kaitan secara langsung. Secara umum penyebaran agama Kristen dan Katolik di wilayah Kalimantan berlangsung sejak abad ke-19 Masehi, seperti yang terjadi di Kalimantan Barat, dan kebanyakan dilaksanakan di pedalaman yang belum didatangi para penyebar agama Islam. Di Kalimantan Timur, agama Kristen dan Katolik bahkan baru masuk pada awal abad ke -20 Masehi (Coomans 1987, 119). Namun demikian, di wilayah Kalimantan Tengah sudah ada upaya untuk menyebarkan agama Kristen pada akhir abad ke-18 Masehi oleh zending Portugis dengan menyusuri Sungai Barito. Selain itu ada juga penyebaran agama Kristen yang melalui Sungai Kapuas, dimulai sejak tahun 1835 yang dirintis oleh Barnstein dari Jerman. Agama Katolik baru masuk
Kalimantan Tengah pada abad 20, yaitu sekitar tahun 1920-an (Rusan dkk 2006, 65-66).

Bangunan gereja rata-rata memiliki bentuk arsitektural yang diadopsi dari berbagai bentuk gereja yang ada di Eropa, antara lain memiliki ruang memanjang, atap tunggal dengan kemiringan yang cukup tinggi, pintupintu dibuat tinggi, dan terdapat salib pada bagian depan. Bahan yang digunakan tentu saja menyesuaikan dengan kondisi di Kalimantan, yaitu kayu. Bersama dengan masjid, bentuk-bentuk arsitektur gereja di Kalimantan juga menyumbangkan warna baru dalam perkembangan arsitektur bangunan. Keduanya memberikan warna bangunan yang asalnya dari wilayah yang terletak di sebelah barat, yaitu kawasan Timur Tengah dan Eropa. Meskipun demikian, pada saat ini sudah banyak gereja kuna yang bentuk aslinya sudah berubah sama sekali. Dari segi arah hadap, tampaknya tidak ada aturan yang baku di dalam pembangunan gereja ini. Dengan demikian, antara satu gereja dengan gereja yang lain dalam satu wilayah saja dapat terjadi arah hadapnya berbeda-beda.

Berbeda dengan masjid dan gereja, kelenteng yang merupakan tempat peribadatan agama yang berasal dari kawasan Asia bagian timur, sehingga warna timurnya sangat menonjol. Meskipun masyarakat Cina berada jauh dari tanah leluhur mereka ratusan tahun yang lalu, namun adat istiadat maupun agama nenek moyang tetap dipegang teguh. Hal tersebut antara lain tercermin dari pendirian kelenteng yang memiliki berbagai makna filosofis. Salah satu contoh adalah untuk menentukan arah hadap kelenteng harus sesuai dengan feng shui supaya dapat memberikan keberkahan. 


\section{Penutup}

Situs-situs keagamaan di Kalimantan menunjukkan bahwa persebaran berbagai agama menghasilkan berbagai budaya yang senafas dengan agama tersebut. Sebagai contoh, untuk keperluan bersembahyang diperlukan sebuah lokasi khusus, sehingga muncul beragam rumah ibadah dari berbagai agama dengan cirinya masing-masing. Keletakan bangunan keagamaan di Kalimantan sebagian besar berada di tepi sungai atau tidak jauh dari aliran sungai, yang merupakan jalan utama lalu lintas dari pantai ke pedalaman maupun sebaliknya. Hal ini juga menandakan bahwa sejak ratusan tahunan tahun yang lalu kawasan tepi sungai sudah menjadi suatu kawasan yang padat penghuni, yang tetap bertahan sampai dengan saat ini. Kota-kota dan kawasan pemukiman munculnya rata-rata juga di tepi sungai, misalnya Pontianak lama, Mempawah Lama, dan Banjarmasin.

Kesinambungan budaya juga tercermin dari pemilihan lokasi situs-situs keagamaan tersebut. Salah satu contoh adalah penentuan lokasi makam pada masa kerajaan Islam, yang masih terpengaruh tradisi masa sebelum Islam. Makam-makam raja atau ulama banyak yang berada di bukit yang meneruskan tradisi lama yang menganggap bukit sebagai tempat suci. Selain di bukit, makam-makam juga banyak yang berada di sekitar masjid yang merupakan bangunan suci.

\section{Referensi}

Anom, I. G. N., dkk. 1999. Masjid kuno Indonesia. Jakarta: Departemen Pendidikan dan Kebudayaan.

Atmodjo, M. M. Soekarto. 1994. Beberapa temuan prasasti baru di Indonesia. Dalam Bambang Sulistyanto, dkk. (ed.) Berkala Arkeologi XVI.

Coomans, Mikhail. 1987. Manusia Dayak, dahulu, sekarang, masa depan. Jakarta: PT. Gramedia.

Daljoeni, Natanael. 1998. Geografi kota dan desa. Bandung: Penerbit Alumni.

Kementrian Kebudayaan dan Pariwisata. 2011. Undang-undang Republik Indonesia Nomor 11 tahun 2010 tentang cagar budaya.

Loir, Henry Chambert dan Claude Guillot. 2007. Ziarah dan wali di dunia Islam. Jakarta: Ecole Francaise d'Extreme Orient Forum Jakarta-Paris.

Rusan, Ahim S., dkk. 2006. Sejarah Kalimantan Tengah. Palangka Raya: Lembaga Penelitian Universitas Palangka Raya.

Thohir, Ajid. 2004. Perkembangan peradaban di kawasan dunia Islam, melacak akar-akar sejarah, politik, dan budaya umat Islam. Jakarta: PT. Raja Grafindo Perkasa. 